\title{
Multiple cues for induction of metamorphosis in larvae of the common mud crab Panopeus herbstii
}

\author{
Raymond A. Rodriguez, Charles E. Epifanio*
}

University of Delaware, College of Marine Studies, Hugh R. Sharp Campus, 700 Pilottown Rd., Lewes, Delaware 19958, USA

\begin{abstract}
Cues associated with biofilms from the adult habitat previously have been found to accelerate metamorphosis in the megalopae of the common mud crab Panopeus herbstii (Milne-Edwards). In this study, we investigated several properties of this biofilm and further investigated the response of megalopae to exudates from adult $P$. herbstii. Results showed the cue to be water-soluble and suggest that it is associated with the bacterial component of the film. Biofilms from a rocky intertidal area produced a response, while films from an intertidal sand flat did not. When biofilm was allowed to form on clean glass slides in adult habitat, megalopae showed a stronger response to 10-d-old biofilms than to 2-d-old biofilms. Exudates from adult P. herbstii produced a strong response while exudates from prey species Crassostrea virginica and a closely related mud crab Dyspanopeus sayi produced a weaker, but significant response. Exudates from fiddler crabs Uca pugnax did not elicit a response. Results from these experiments suggest that there are multiple water-soluble cues that induce metamorphosis of mud crab megalopae.
\end{abstract}

KEY WORDS: Mud crab - Megalopae $\cdot$ Metamorphosis $\cdot$ Biofilm $\cdot$ Exudate

\section{INTRODUCTION}

Factors that influence the settlement of marine invertebrate larvae in juvenile habitat have been the subject of intense investigation for more than a quarter of a century (for reviews see Meadows \& Campbell 1972, Morse 1990, Pawlik 1992). Finely tuned control of settlement is particularly critical for sessile forms wherein juveniles have very limited ability to move to new localities or may be permanently attached to the substratum after metamorphosis. Such species often respond to chemical cues that allow competent larvae to identify juvenile habitat and to undergo accelerated metamorphosis after settlement. While the chemical structure of these cues has been identified in only a few cases, the cues appear to emanate from a variety of sources, including conspecific adults, closely associated prey species, and biofilms attached to the substratum (Rodriguez et al. 1993).

In contrast to sessile forms, the juveniles of mobile species are not restricted to the area in which settle-

- Corresponding author. E-mail: epi@udel edu ment occurs, but have the ability to move to alternative habitat as conditions dictate. Accordingly, the processes that govern settlement and metamorphosis of these species have received much less attention. Recent investigations, however, have demonstrated that juvenile forms of mobile species may have very specific requirements for nursery habitat and may possess highly evolved adaptations for identifying that habitat

A case in point is the common mud crab Panopeus herbstii (family: Xanthidae). This species is the most abundant crab in mesohaline regions of many estuaries along the east coast of temperate North America (Williams 1984). Juvenile $P$. herbstii consume a variety of small invertebrates (McDonald 1977. Dame \& Patten 1981), while adults are effective predators of co-occurring bivalve mollusks (McDermott \& Flower 1952, McDermott 1960, Meyer 1994). Studies have shown that $P$. herbstii is a major predator of juvenile oysters and has a significant effect on the yield of oyster fisheries in Chesapeake and Delaware Bays (Whetstone \& Eversole 1981, Lin 1990, Abbe \& Breitburg 1992). $P$. herbstii is also an important pest in bivalve mariculture 
systems and has been identified as a major predator of juvenile hard clams in field grow-out operations (Castagna \& Kraeuter 1977, Flimlin \& Beal 1993).

In Delawarc Bay (ca $39^{\circ} \mathrm{N}, 75^{\circ} \mathrm{W}$ ), adult Panopeus herbstii spawn throughout the summer months. Larval development includes 4 zoea stages and a megalopa stage. Zoeal development lasts approximately $2 \mathrm{wk}$, and the megalopa stage may extend another 2 to 3 wk under natural conditions (Epifanio et al. 1994). Oyster reefs, cobble bottoms, and rocky intertidal areas provide habitat for juvenile and adult $P$. herbstii (Ryan 1956, McDonald 1982). These environments allow both refuge from predation and easy access to food (Fernandez et al. 1993, Dittel et al. 1996). Adult $P$. herbstii are unable to swim and undoubtedly have a very limited home range. Thus, the habitat of the adult form is largely determined at the time of settlement.

The specific nature of cues for metamorphosis of decapod crustaceans is not well known. Results of some investigations suggest a primary role for the structural or textural characteristics of the substratum (e.g. Herrnkind \& Butler 1986, Day \& Lawton 1988). Other studies implicate biogenic, water-soluble compounds in the settlement process (e.g. Wolcott \& DeVries 1994, Brumbaugh \& McConaugha 1995, Forward et al. 1997. Welch et al. 1997, Fitzgerald et al. 1998, Gebauer et al. 1998). Additional investigations suggest a response to sediment associated with adult habitat (Christy 1989, O'Connor 1997)

However, there has been little study of the role of microbial biofilms in the settlement and metamorphosis of decapods. The only available data come from an earlier investigation conducted in our laboratory (Weber \& Epifanio 1996) and to some extent from a recent study by Gebauer et al. (1998). Results from the former study showed a clear response of Panopeus herbstii megalopae to cues associated with preferred adult habitat. Natural substratum from adult habitat consistently induced metamorphosis, whereas clean structural mimics of this substratum failed to induce a response. However, biofilm-covered mimics induced metamorphosis comparable to that in the natural substratum. This suggests a cue that is closely tied to the existence of a biofilm on the surface of the preferred substratum.

In this paper we present results of further investigations into the role of chemical cues as inducers of metamorphosis in the megalopa stage of Panopeus herbstii (Milne-Edwards). The present study specifically addresses the question of water-solubility of the putative cues, compares the effectiveness of biofilms cultured under a variety of conditions in the natural environment, and examines the response of megalopae to exudates from adult $P$. herbstii and from other species that occur in adult habitat.

\section{MATERIALS AND METHODS}

General aspects of experiments. Megalopae used in the experiments were the progeny of wild ovigerous females collected from rocky intertidal habitat. Females were held under laboratory conditions until hatching $\left(25^{\circ} \mathrm{C}, 30 \%, 14 \mathrm{~h}\right.$ light $/ 10 \mathrm{~h}$ dark), and zoea larvae were reared using standard techniques (e.g. Welch \& Epifanio 1995). Upon molting to the megalopa stage, individuals were immediately placed in large glass bowls of filtered offshore seawater at 50 megalopae per bowl $\left(25^{\circ} \mathrm{C}, 30 \%\right.$, $14 \mathrm{~h}$ light $/ 10 \mathrm{~h}$ dark $)$. Because our earlier work had shown that larvae are not competent to metamorphose for the first $9 \mathrm{~d}$ after molting to the megalopa stage (Weber \& Epifanio 1996), all individuals were in the range of 10 to $11 \mathrm{~d}$ post-megalopal molt when initially exposed to experimental conditions

Protocol always included 6 replicates of each treatment. Each replicate consisted of 10 megalopae in a glass finger bowl (19 cm diameter) containing $600 \mathrm{ml}$ of filtered offshore seawater and the appropriate experimental or control treatment. Offshore water was obtained approximately $25 \mathrm{~km}$ seaward of the mouth of Delaware Bay, Delaware, USA, and was filtered to remove particles $>5 \mu \mathrm{m}$. Results of previous work had shown that offshore water, in the absence of other cues, does not induce metamorphosis of Panopeus herbstii megalopae (Weber \& Epifanio 1996).

Five experiments were conducted in all, and results of each experiment were analyzed separately. Each experiment employed a positive control (pebbles and shell fragments from natural adult habitat) and a negative control (offshore water alone). These controls were identical to those used in earlier studies of metamorphosis in Panopeus herbstii (Weber \& Epifanio 1996). The duration of each experiment was $10 \mathrm{~d}$, and the dependent variable was mean time to metamorphosis. Individuals that survived the entire duration of the experiment, but did not metamorphose, were arbitrarily assigned a time-to-metamorphosis value of $10 \mathrm{~d}$. The great majority of these individuals were in the negative control treatments. Thus, the mean time to metamorphosis in the negative control was always conservative.

Statistical analysis consisted of a nested, 1-way ANOVA followed by Tukey's HSD multiple comparison test. The nested ANOVA allowed inference concerning: (1) significant differences among bowls within each treatment ( $n=6$ bowls per treatment) and (2) significant differences among treatments ( $n=60$ megalopae per treatment). The HSD multiple comparison test was used to assess discrete treatment effects in the case of significant ANOVA results. Inference was always made at $\alpha=0.05$. 
At initiation of each experiment, 10 megalopae were assigned haphazardly to each replicate bowl within the respective treatments. Megalopae were fed a daily ration consisting of freshly hatched nauplii of the brine shrimp Artemia sp. Bowls were monitored for survival and metamorphosis each day, and megalopae were transferred to clean bowls containing the appropriate treatment every other day. All experiments were conducted under the same controlled environmental conditions $\left(25^{\circ} \mathrm{C}, 30 \%\right.$, $14 \mathrm{~h}$ light $/ 10 \mathrm{~h}$ dark $)$.

Biofilms were grown on clean glass microscope slides $(75 \times 25 \mathrm{~mm})$ that were moored to the substratum in the natural environment; this process was termed 'conditioning the slides'. Slides in the first biofilm experiment were placed loosely in a mesh bag which was then anchored to the bottom. In the remainder of the biofilm experiments, slides were held individually in slots of a plastic slide rack that had been perforated to allow free flow of water. Slides that were conditioned in the racks developed more extensive biofilms than those grown in the mesh bags. This had an apparent effect on the outcome of the experiments (see 'Results'). Slides were conditioned for $7 \mathrm{~d}$ before use in an experiment.

The slides were usually conditioned in the rocky intertidal zone in the University of Delaware Harbor, where adult Panopeus herbstii are very common. But in 1 experiment we compared the activity of slides conditioned in adult habitat to that of slides conditioned at a nearby sand flat where adult $P$. herbstii do not occur. Regardless of habitat, slides were always conditioned midway between the mean high-water and mean lowwater marks. All slides were gently rinsed in filtered offshore water to remove excess debris before use in experiments. Biofilm treatments were prepared by placing 3 slides in the center of each bowl in $600 \mathrm{ml}$ of filtered offshore water. Megalopae were introduced to the bowls $24 \mathrm{~h}$ later, which allowed the leaching of any water-soluble cues into the water.

Biofilm experiments. Our investigation of the role of biofilms in producing cues for metamorphosis involved 4 experiments. In the first experiment (Biofilm 1) we tested the hypothesis that the cue associated with biofilm from adult habitat is water-soluble. We did this by exposing the first group of megalopae to biofilmcovered slides that were held in cages, while a second group was exposed to conditioned slides that were freely accessible on the bottom of the bowls. In both cases the slides had been conditioned for $7 \mathrm{~d}$ in adult habitat. The cages were constructed from perforated PVC cylinders $(2.5 \mathrm{~cm}$ height $\times 7.6 \mathrm{~cm}$ diameter covered with $253 \mathrm{\mu m}$ Nitex mesh. Preliminary observations indicated that the cages were effective in preventing megalopae from direct contact with the slides, while still allowing any water-soluble cue to exit the cage and permeate the remaining water in the bowl. Each replicate consisted of 3 conditioned slides inside a cage that was placed centrally in the bowl. Presumably, the megalopae in this treatment would respond by metamorphosing only if the cue was water-soluble. The non-caged treatment also utilized 3 slides per replicate. Because earlier work in our laboratory had shown that clean (i.e. no biofilm) 3-dimensional substratum does not induce metamorphosis (Weber \& Epifanio 1996), we were confident that observed effects would be caused by the biofilm on the slides and not by the presence or absence of slides or cages

In a second biofilm experiment (Biofilm 2) we investigated the respective roles of the algal and bacterial components of the biofilm in producing cues for metamorphosis. We compared the activity of slides that had been conditioned in adult habitat in constant darkness under an opaque plastic cover to that of slides conditioned at the same site but with full exposure to the natural diel cycle of light and darkness. It was assumed that if algae were the source of the cue, the biofilm treatment conditioned in the presence of light would elicit a stronger response, while if the bacteria were the source, there would be no difference in response to the 2 treatments.

In order to determine the densities of bacteria and algae in the 2 types of biofilm, we conditioned a number of additional slides under the same respective light/dark conditions. Slides were removed from racks, rinsed gently in filtered offshore water, fixed for $10 \mathrm{~min}$ in $2 \%$ formaldehyde, rinsed with de-ionized water, dried, and frozen. Immediately before analysis, slides were stained with a $1 \mu \mathrm{g} \mathrm{m} \mathrm{m}^{-1}$ DAPI solution for $5 \mathrm{~min}$. Bacteria and algae were then enumerated at $1000 \times$ magnification under UV light. Bacteria were viewed using blue excitation, and algal cells were viewed using red excitation. Respective bacterial and algal counts were performed in 10 random fields (area = $0.01 \mathrm{~mm}^{2}$ ) on each slide.

In Biofilm 3 we addressed the hypothesis that slides conditioned in different habitats vary in their ability to accelerate metamorphosis. In this investigation we compared the ability of biofilms produced in adult habitat (rocky intertidal) to accelerate metamorphosis with that of biofilms produced at a site where adult Panopeus herbstii does not occur (intertidal sand flat). Bacterial densities were determined for biofilms used in each of the treatments.

In Biofilm 4 we tested the hypothesis that films of different age vary in their ability to accelerate metamorphosis. Slides used in the different treatments were conditioned in the rocky intertidal habitat under a natural light/dark cycle in adult habitat for $2,4,6,8$, and $10 \mathrm{~d}$, respectively. We determined bacterial densities on representative slides from each treatment. 
Table 1. Effect of biofilms and exudates on metamorphosis of panopeus herbstii. Summary of nested 1-way ANOVA for all experiments

\begin{tabular}{|llr|}
\hline Expt & Treatment & p-value \\
\hline Biofilm 1 & Cage/uncaged & $<0.001$ \\
& Bowls & 0.304 \\
Biofilm 2 & Light/dark & $<0.001$ \\
& Bowls & 0.365 \\
Biofilm 3 & Location & $<0.001$ \\
& Bowls & 0.937 \\
Biofilm 4 & Age of biofilm & $<0.001$ \\
& Bowls & 0.905 \\
Exudate & Sources of exudates & $<0.001$ \\
& Bowls & 0.808 \\
\hline
\end{tabular}

Exudate experiment. This experiment tested the hypothesis that megalopa larvae respond only to exudate from adult Panopeus herbstii and that exudate from cooccurring species does not induce metamorphosis. Exudate was prepared by placing the source organisms in a $10 \mathrm{l}$ plastic vat with $4 \mathrm{l}$ of filtered offshore water for $48 \mathrm{~h}$. We obtained exudate from adult $P$. herbstii, from the closely related mud crab Dyspanopeus sayi, and from the fiddler crab Uca pugnax. We used 2 to $3 P$. herbstii (5.0 to $5.2 \mathrm{~g}), 2$ to $3 \mathrm{D}$. sayi ( 4.5 to $5.5 \mathrm{~g}$ ), and 2 to $3 U$. pugnax ( 3.8 to $4.8 \mathrm{~g}$ ). Exudate was also obtained from oysters Crassostrea virginica collected from adult

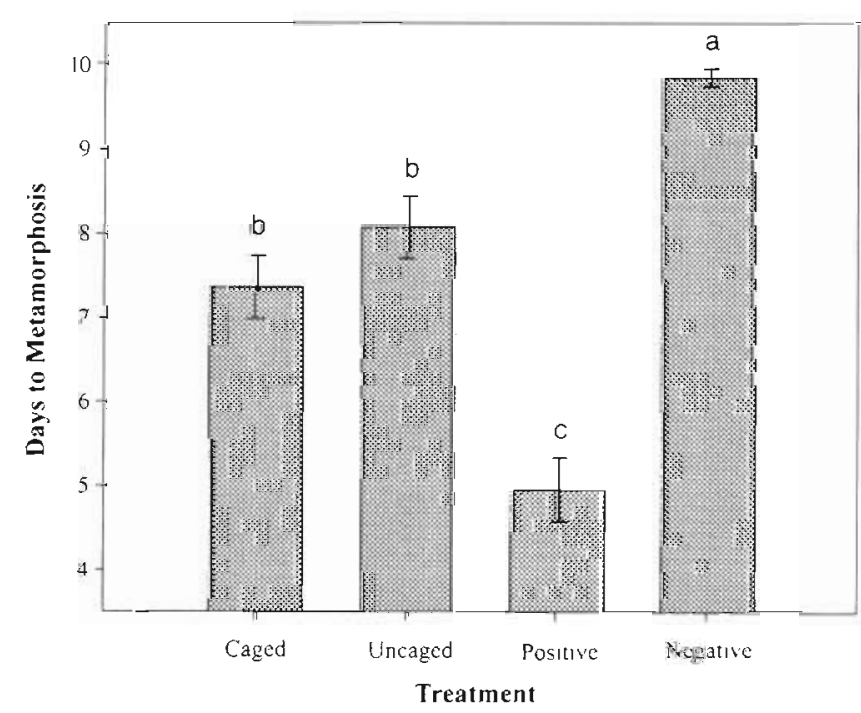

Fig. 1. Biofilm 1. Effect of biofilms on metamorphosis of Panopeus herbstii. Response of megalopa larvae. Bars represent mean days to metamorphosis ( \pm SE). Treatments with different letters are significantly different $(\alpha=0.05$, Tukey's HSD multiple comparison test). Caged and uncaged treatments: biofilm-covered microscope slides from adult habitat, positive control: natural substratum from adult habitat, negative control: offshore sea water habitat in the harbor. A single oyster was used for production of each batch of exudate. In the first treatment, the oyster was scrubbed with a stiff-bristled brush to remove biofilm from the valves. In the second treatment, the biofilm on the oyster valves was left intact. The wet weights of the scrubbed and natural oysters were 29 and $24 \mathrm{~g}$, respectively.

\section{RESULTS}

Results of nested ANOVA showed a significant effect of treatment on the mean time to metamorphosis (MTM) in each of the 5 experiments (Table 1). However, there were no significant differences among bowls within any of the treatments, i.e. effects of the respective treatments were consistent across replicates. In the detailed description below, we present the results of Tukey's HSD multiple comparison test for each of the experiments. This a posterion test allowed determination of discrete differences among MTM values resulting from the various treatments.

\section{Biofilm experiments}

The positive control elicited the shortest time to metamorphosis in Biofilm 1 (Fig. 1). However, this difference between the activity of the positive control and the respective biofilm treatments was not observed in subsequent experiments. This may have been due to differences in the technique used to condition the slides. In Biofilm 1, slides were held loosely in mesh bags moored to the substratum in adult habitat, allowing the slides to form loose stacks and perhaps inhibiting biofilm growth on parts of the slides. In subsequent experiments, slides were placed individually in slots within racks, allowing more free flow of water around them and therefore allowing more space for biofilm growth on both sides of each slide.

Even so, there was a significant difference between MTM in the biofilm treatments and in the negative control in Biofilm 1, indicating that the biofilms were active accelerators of metamorphosis. Moreover, there was no significant difference in MTM between the caged and uncaged biofilm treatments, indicating that induction of metamorphosis did not depend on physical contact between the megalopae and the biofilm.

Results from Biofilm 2 showed no significant difference in time to metamorphosis among the dark biofilm, light biofilm, and positive control treatments (Fig. 2). Bacterial density was similar in the 2 biofilms while algal densities were approximately 4 times greater in the light treatment than in the dark treatment (Table 2). Because photosynthetic activity was presum- 


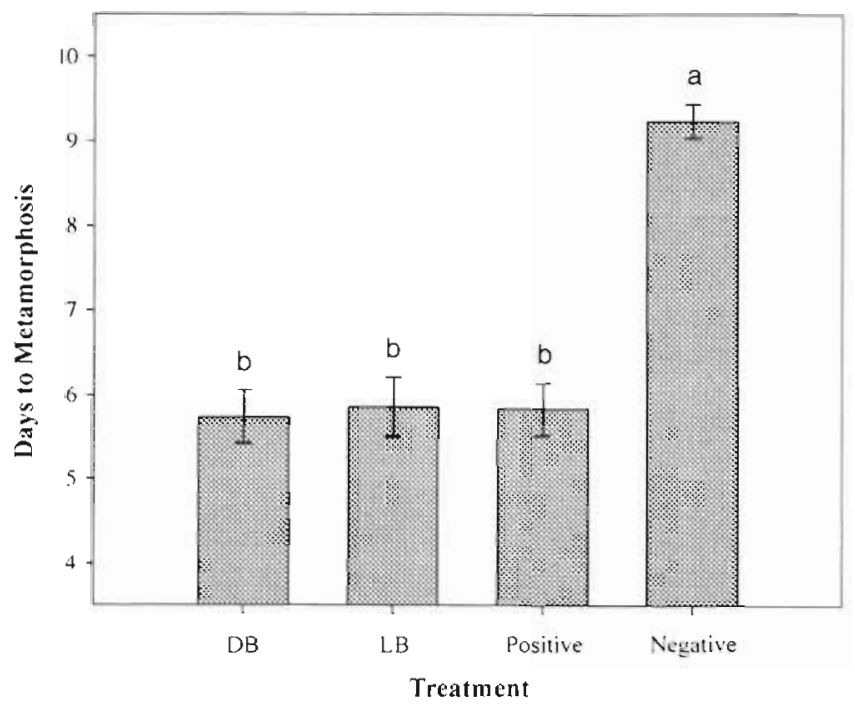

Fig. 2. Biofilm 2. See Fig. 1 for explanation. DB: 5 lides conditioned in darkness, LB: slides conditioned in sunlight, positive control: natural substratum from adult habitat, negative control: offshore sea water

ably zero in darkness, the algal populations on the dark-conditioned slides were not growing, and the cells that we observed on these slides were probably recent settlers from the surrounding water column.

In Biofilm 3 there was a significant difference in the activity of slides conditioned at the different sites, as the MTM was shorter in the rocky intertidal than in the sandy intertidal treatment (Fig. 3). Moreover, there was no significant difference between MTM in the sandy intertidal treatment and in the negative control. However, the bacterial densities were similar on slides conditioned at the rocky intertidal and sandy intertidal sites, which suggests that the taxonomic composition of the bacterial assemblages at the 2 sites must have differed considerably (Table 3 ).

Table 2. Effect of biofilms on metamorphosis of Panopeus herbstii. Bacterial and algal densities of biofilms grown in darkness and in sunlight. Densities are bacteria cells $\mathrm{cm}^{-2}$ (-) Damaged slides

\begin{tabular}{|lcc|}
\hline Replicate & Dark-grown biofilms & Light-grown biofilms \\
\hline Bacteria & & \\
1 & $2.5 \times 10^{6}$ & $3.3 \times 10^{6}$ \\
2 & $1.7 \times 10^{6}$ & $2.7 \times 10^{6}$ \\
3 & $2.6 \times 10^{5}$ & - \\
Mean & $2.3 \times 10^{6}$ & $3.0 \times 10^{6}$ \\
Algae & & \\
1 & $1.7 \times 10^{3}$ & $5.3 \times 10^{3}$ \\
2 & $2.0 \times 10^{3}$ & $4.0 \times 10^{3}$ \\
3 & 0.0 & - \\
Mean & $1.2 \times 10^{3}$ & $4.7 \times 10^{3}$ \\
\hline
\end{tabular}

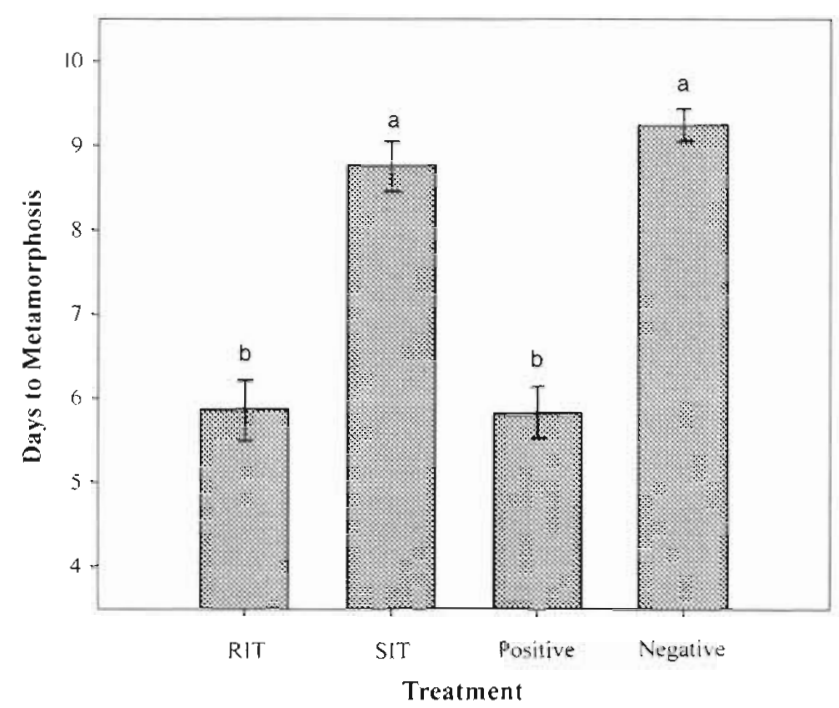

Fig. 3. Biofilm 3. See Fig. 1 for explanation. RIT: slides conditioned in rocky intertidal, SIT slides conditioned in sandy intertidal, positive control: natural substratum from adult habitat, negative control: offshore sea water

In Biofilm 4 the groups that were exposed to slides conditioned in adult habitat for 8 or $10 \mathrm{~d}$ showed the shortest MTM (Fig. 4). But even the group exposed to slides conditioned for as little as $2 \mathrm{~d}$ showed accelerated metamorphosis compared to the negative control. Differences among the other treatments were less clear, and results of the statistical analysis showed considerable overlap in the magnitude of the effects. However, there was a significant difference in bacterial density on slides conditioned for 2 d compared to those conditioned for a longer period (Table 4).

\section{Exudate experiment}

Exudates from adult mud crabs and from other species associated with adult habitat also induced metamorphosis. Strongest responses were elicited by Panopeus herbstii exudate and by the positive control, wherein MTM was approximately 6 d (Fig. 5). Res-

Table 3. Effect of biofilms on metamorphosis of Panopeus herbstii. Bacterial densities of biofilms grown in different habitats. Densities are bacteria cells $\mathrm{cm}^{-2}$ (-) Damaged slides

\begin{tabular}{|lcc|}
\hline Replicate & Rocky intertidal & Sand flat \\
\hline 1 & $3.29 \times 10^{6}$ & $3.28 \times 10^{6}$ \\
2 & $2.70 \times 10^{6}$ & $5.48 \times 10^{6}$ \\
3 & - & $2.37 \times 10^{6}$ \\
4 & - & $2.55 \times 10^{6}$ \\
Mean & $3.00 \times 10^{6}$ & $3.41 \times 10^{6}$ \\
\hline
\end{tabular}




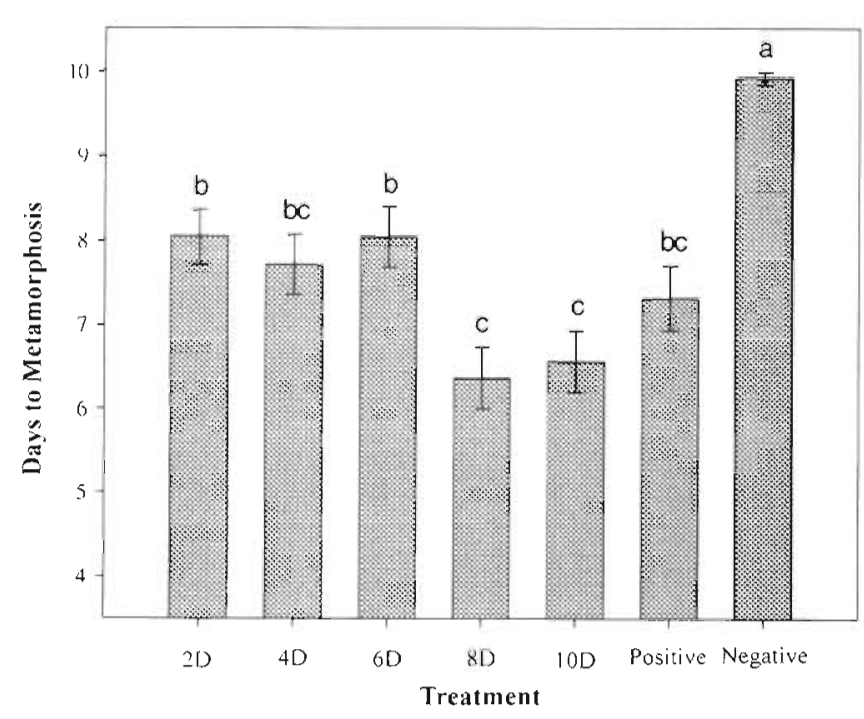

Fig. 4. Biofilm 4. See Fig. 1 for explanation. 2D, 4D, etc.: slides conditioned for different lengths of time (2 to $10 \mathrm{~d}$ ) in adult habitat, positive control: natural substratum from adult habi tat, negative control: offshore sea water

ponses to the scrubbed and natural oyster exudates did not differ, but were intermediate between the positive and negative controls. Exudate from a closely related species of mud crab Dyspanopeus sayi induced a response similar to the oyster exudates, but greater than the response elicited by exudate from the distantly related fiddler crab Uca pugnax, which was essentially inactive.

\section{DISCUSSION}

Results of these experiments provide strong evidence that multiple cues exist for induction of metamorphosis in the mud crab Panopeus herbstii. Furthermore, there seems little doubt that the cues are water-soluble and that contact with the actual source

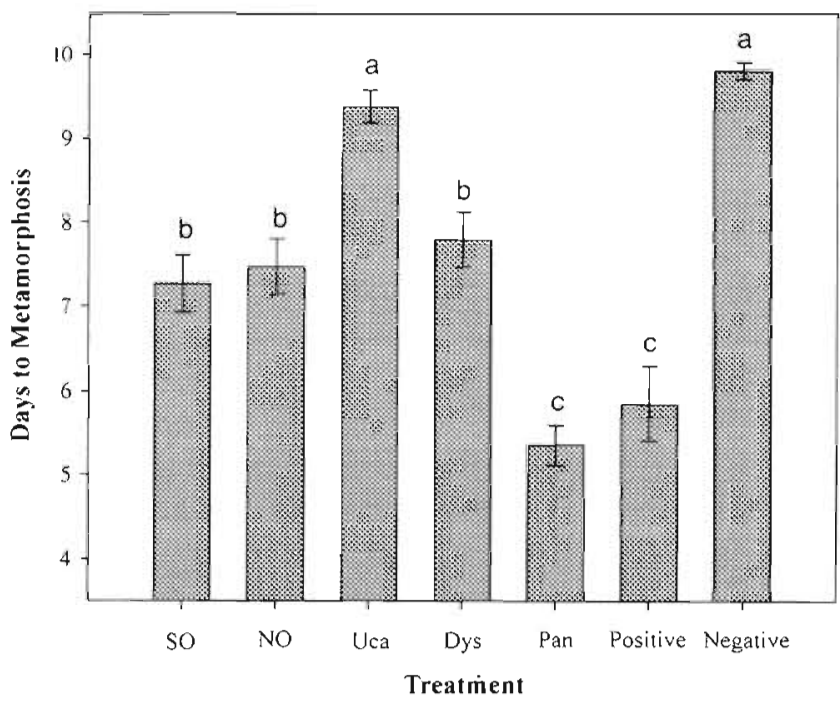

Fig. 5. Exudate experiment. See Fig. 1 for explanation. SO: exudates from scrubbed oyster, NO: natural oyster, Uca: fiddler crab Uca pugnax, Dys: mud crab Dyspanopeus sayi, Pan: Panopeus herbstii, positive control: natural substratum from adult habitat, negative control: offshore sea water

of the cue is not necessary for induction of the response. Similar water-soluble cues have been suggested for a number of invertebrate species representing a variety of phyla (Hadfield \& Pennington 1990, Pearce \& Scheibling 1990, Lambert \& Todd 1994, Zimmer-Faust \& Tamburri 1994), and indeed were suggested in earlier work with the megalopae of $P$. herbstii (Weber \& Epifanio 1996).

Because we were unsuccessful in conditioning slides that were totally devoid of algal cells, we are unable to absolutely exclude a role for algae in production of cues. Nevertheless, there was no difference in the activity of slides conditioned in darkness or under a normal diel light cycle, in spite of a 4 -fold difference in the density of algal cells in the respective treatments. Presumably, there was no photosynthetic activity in algal cells on the dark-conditioned

Table 4. Effect of biofilms on metamorphosis of Panopeus herbstii. Bacterial densities of biofilms grown for different periods of time in adult habitat. Densities are bacteria cells $\mathrm{cm}^{-2}$

\begin{tabular}{|c|c|c|c|c|c|}
\hline Replicate & $2 d$ & $4 \mathrm{~d}$ & $\begin{array}{c}\text { Biofilm age } \\
6 \mathrm{~d}\end{array}$ & $8 \mathrm{~d}$ & $10 \mathrm{~d}$ \\
\hline 1 & $1.24 \times 10^{6}$ & $3.46 \times 10^{6}$ & $3.08 \times 10^{6}$ & $2.71 \times 10^{6}$ & $1.95 \times 10^{6}$ \\
\hline 2 & $1.16 \times 10^{6}$ & $1.59 \times 10^{6}$ & $3.96 \times 10^{6}$ & $4.59 \times 10^{6}$ & $4.00 \times 10^{6}$ \\
\hline 3 & $5.75 \times 10^{5}$ & $4.93 \times 10^{6}$ & $3.33 \times 10^{6}$ & $4.15 \times 10^{6}$ & $4.40 \times 10^{6}$ \\
\hline 4 & $5.73 \times 10^{5}$ & $4.59 \times 10^{6}$ & $1.60 \times 10^{6}$ & $5.86 \times 10^{6}$ & $5.19 \times 10^{6}$ \\
\hline 5 & $6.88 \times 10^{5}$ & $1.65 \times 10^{6}$ & $2.64 \times 10^{6}$ & $5.11 \times 10^{6}$ & $5.12 \times 10^{6}$ \\
\hline 6 & $6.96 \times 10^{5}$ & $3.83 \times 10^{6}$ & $2.71 \times 10^{6}$ & $6.08 \times 10^{6}$ & $6.21 \times 10^{6}$ \\
\hline Mean & $8.22 \times 10^{5}$ & $3.34 \times 10^{6}$ & $2.89 \times 10^{6}$ & $4.74 \times 10^{6}$ & $4.48 \times 10^{6}$ \\
\hline
\end{tabular}


slides, which would result in an accompanying decrease in the overall metabolic activity of the algae. Thus, the cue in this case seems more likely to be a metabolic product of the bacteria. Because settlement of mud crabs is of no apparent benefit to the bacteria, it is most probable that Panopeus herbstii has simply evolved the capacity to utilize these compounds with no attendant co-evolutionary adaptation on the part of the bacteria, i.e. the bacteria are passive players in the process.

Bacteria also have been found to play a role in the settlement and metamorphosis of other invertebrate species. Larvae of the crown-of-thorns star fish Acanthaster planci metamorphose more rapidly when in the presence of the bacterium Lithothamnium pseudosorum (Johnson \& Sutton 1994). Similarly, Kirchman et al. (1982) found that the polychaete worm Janua brasiliensis settled on multi-species bacterial films grown from bacteria associated with the seaweed Ulva lobata, but did not settle on films comprised almost entirely of the diatom Nitzschia. Again, this is similar to the results found in the present experiment. The polychaete study also demonstrated that bacteria do not need to be viable in order to produce a response, since the larvae responded to bacteria that had been treated with antibiotics or formaldehyde. Apparently, the larvae were responding to polysaccharides on the surface of the bacteria.

In our experiments, biofilms grown in non-adult habitat (intertidal sand flat) did not induce metamorphosis in Panopeus herbstii megalopae, even though the densities of bacteria on sand-flat conditioned slides were similar to densities obtained at the rocky intertidal site. Other examples exist regarding selective settlement in favorable habitat by decapod crustaceans. Jensen (1989) found gregarious settlement by the anomuran crabs Petrolisthes cinctipes and Petrolisthes eriomerus, and megalopa larvae of the blue crab Callinectes sapidus have been shown to settle and metamorphose in response to water-soluble cues associated with juvenile habitat (Forward et al. 1994, 1996, Welch et al. 1997).

In the case of Panopeus herbstii, the duration of conditioning appears to play a role in the activity of biofilms. In our experiments, there was a significant difference in time to metamorphosis in megalopae exposed to slides conditioned in adult habitat for 8 to $10 \mathrm{~d}$ compared to slides conditioned for a shorter period of time. However, there was no significant increase in bacterial density after the first $4 \mathrm{~d}$ of conditioning, which suggests that some factor other than simple bacterial numbers may be involved in the process. Pearce \& Scheibling (1991) came to a similar conclusion in their study of the effect of conditioning time on the ability of biofilm to induce metamorphosis in the sea urchin Strongylocentrotus droebachiensis.
Other studies dealing with correlations between biofilm age and activity have been performed on sessile organisms such as bryozoans (Maki et al. 1989, Keough \& Raimondi 1995) and polychaetes (Keough \& Raimondi 1995). These studies generally agree that older films ( 4 to $6 \mathrm{~d}$ ) tend to initiate a stronger response than younger films.

Results of our investigation also showed a strong response to exudate from adult Panopeus herbstii. Exudate from a closely related species Dyspanopeus sayi was significantly more active than exudate from the taxonomically distant fiddler crab Uca pugnax but not nearly as potent as exudate from P. herbstii. This is in agreement with the findings of Weber \& Epifanio (1996), which indicated that exudate from the blue crab Callinectes sapidus did not affect time to metamorphosis in mud crab megalopae. The muted, but statistically significant, cross-species activity of exudates from $D$. sayi and $P$. herbstii may be related to a difference in the quantity of the cue produced. Another possibility is that the molecular structure of the cue from D. sayi is similar but not identical to the cue produced by $P$. herbstii, thus resulting in a reduced response. However, in a related study Jensen (1989) found that megalopae from the crab Petrolisthes cinctipes did not show gregarious settlement in response to adults from the congeneric species Petrolisthes eriomerus. Thus, the cross-species activity of exudate from closely related crabs is not universal.

The cue found in the exudate from Panopeus herbstii has been partially characterized in recent work by Andrews (1999). The active fraction of the exudate appears to be a small, water-soluble peptide $(<1000 \mathrm{Da})$ that maintains its activity after exposure to both high $\left(100^{\circ} \mathrm{C}\right)$ and low temperature $\left(-20^{\circ} \mathrm{C}\right)$. The cue also appears to be effective at low concentrations, as Andrews found significant activity when the cue was diluted by a factor of $10^{-3}$ compared to the concentration used in our experiment.

Results of our investigation also showed a response of Panopeus herbstii megalopae to exudate from a potential prey species, the oyster Crassostrea virginica. While the response was muted compared to exudate from $P$. herbstii, it was significantly greater than response to the negative control and was not diminished by removal of biofilm from the valves of the oyster. This appears to be the first time that a prey-associated cue has been implicated in the metamorphosis of crab megalopae, but a similar response has been reported for a variety of species of molluscan and echinoderm larvae (Barnes \& Gonor 1973, Hadfield \& Scheuer 1985, Rowley 1989, Bahamondes-Rojas \& Dherbomez 1990, Pearce \& Scheibling 1991, Lambert \& Todd 1994). Furthermore, a number of prey-associated cues that have been shown to induce metamorphosis in 
dorid nudibranchs have proven to be water-soluble, which is in agreement with the results from the present study (Hadfield \& Scheuer 1985, Bahamondes-Rojas \& Dherbomez 1990, Lambert \& Todd 1994).

All things considered, the results of our experiments indicate that competent megalopa larvae of Panopeus herbstii respond to a water-soluble cue, or set of cues, emanating from several sources associated with adult habitat. At this point, we cannot exclude the possibility of a single cue produced independently by the different sources. Nevertheless, this seems improbable given the wide taxonomic diversity of the source organisms. A more plausible explanation is that multiple sources produce several different chemical compounds that induce metamorphosis in mud crab megalopae. The compounds may be structurally similar and chemoreceptors may be unable to distinguish between them. This seems quite likely in the case of the crossspecies activity of exudates from closely related forms like Dyspanopeus sayi and $P$. herbstii. However, $P$. herbstii may well have evolved different sets of chemoreceptors that can each detect cues emanating from a wide variety of taxonomically unrelated sources that occur in adult habitat. Resolution of this question awaits results of ongoing studies concerning isolation and characterization of the various cues used in the present investigation.

Acknowledgements. This study was supported by funds from the University of Delaware Sea Grant College Program Essential technical assistance was provided by Brandon Jones, Robert Andrews, Cecily Natunewicz, and Sandy Schwalm. Experiments described in the paper comply with current laws of the United States of America.

\section{LITERATURE CITED}

Abbe GR, Breitburg DL (1992) The influence of oyster toadfish (Opsanus tau) and crabs (Callinectes sapidus and Xanthidae) on survival of oyster (Crassostrea virginica) spat in Chesapeake Bay: does spat protection always work? Aquaculture 107:21-31

Andrews WR (1999) Isolation and characterization of the metamorphic inducer of the common mud crab, Panopeus herbstii. Masters thesis, University of Delaware, Newark

Bahamondes-Rojas I, Dherbomez M (1990) Partial purification of a glycoconjugate substance capable of inducing metamorphosis in competent larvae of Eubranchus doriae (Trinchese 1879), a nudibranch mollusc. J Exp Mar Biol Ecol 144:17-27

Barnes JR, Gonor JJ (1973) The larval settling response of the lined chiton Tonicella Lineata. Mar Biol 20:259-264

Brumbaugh RD, McConaugha JR (1995) Time to metamorphosis of blue crab Callinectes sapidus megalopae: effects of benthic macroalgae. Mar Ecol Prog Ser 129:113-118

Castagna M, Kraeuter JN (1977) Mercenaria culture using stone aggregate for predator protection. Proc Natl Shellfish Assoc 67:1-6

Christy JH (1989) Rapid development of megalopae of the fiddler crab Uca pugilator reared over sediment: implica- tions for models of larval recruitment. Mar Ecol Prog Ser 57:259-265

Dame RT, Patten BC (1981) Analysis of energy flows in an intertidal oyster reef. Mar Ecol Prog Ser 5:115-124

Day EA, Lawton P (1988) Mud crab (Crustacea: Brachyura: Xanthidae) substrate preference and activity. J Shellfish Res 7:421-426

Dittel A, Epifanio CE. Natunewicz C (1996) Predation on mud crab megalopae, Panopeus herbstij H. Milne Edwards: effect of habitat complexity, predator species and postlarval densities. J Exp Mar Biol Ecol 198:191-202

Epifanio CE, Lobanoff ML, Connaughton VP, Welch J (1994) Growth and development of mud crab larvae in fielddeployed enclosures and in the laboratory. J Exp Mar Biol Ecol 180:165-174

Fernandez M, Iribarne O. Armstrong D (1993) Habitat selection by young-of-the-year Dungeness crab Cancer magister and predation risk in intertidal habitats. Mar Ecol Prog Ser 92:171-177

Fitzgerald TP, Forward RB Jr, Tankersley RA (1998) Metamorphosis of the estuarine crab Rhithropanopeus harrisii: effect of water type and adult odor. Mar Ecol Prog Ser 165:217-223

Flimlin G, Beal BF (1993) Major predators of cultured shellfish. Northeastern Regional Aquaculture Center Bulletin No. 180. University of Massachusetts, Dartmouth

Forward RB Jr, DeVries MC, Rittschof $\mathrm{D}$, Frankel DAZ, Bischoff JP, Fisher CM, Welch JM (1996) Effects of environmental cues on metamorphosis of the blue crab Callinectes sapidus. Mar Ecol Prog Ser 131:165-177

Forward RB Jr, Frankel DAZ, Rittschof D (1994) Molting of megalopae from the blue crab Callinectes sapidus: effects of offshore and estuarine cues. Mar Ecol Prog Ser 113:55-59

Forward RB Jr, Tankersley RA, Blondel D, Rittschof D (1997) Metamorphosis of the blue crab Callinectes sapidus: effects of humic acids and ammonium. Mar Ecol Prog Ser 157:277-286

Gebauer P, Walter I, Anger WK (1998) Effects of substratum and conspecific adults on the metamorphosis of Chasmagnathus granulata (Dana) (Decapoda: Grapsidae) megalopae. J Exp Mar Biol Ecol 223:185-198

Hadfield MG, Scheuer D (1985) Evidence for a soluble metamorphic inducer in Phestilla: ecological, chemical and biological data. Bull Mar Sci 37:556-566

Hadfield $M G$, Pennington JT (1990) The nature of the metamorphosis signal and its internal transduction in larvae of the nudibranch Phestilla sibogae. Bull Mar Sci 46:455-464

Herrnkind WF, Butler M JJV (1986) Factors regulating postlarval settlement and juvenile microhabitat use by spiny lobsters Panulirus argus. Mar Ecol Prog Ser 34:23-30

Jensen GC (1989) Gregarious settlement by megalopae of the porcelain crabs Petrolisthes cinctipes (Randall) and $P$. eriomerus Stimpson. J Exp Mar Biol Ecol 131:223-231

Johnson CR, Sutton DC (1994) Bacteria on the surface of crustose coralline algae induce metamorphosis of crown-ofthorns starfish Acanthaster planci. Mar Biol 120:305-310

Keough MJ, Raimondi PT (1995) Responses of settling invertebrate larvae to bioorganic films: effects of different types of films. J Exp Mar Biol Ecol 185:235-253

Kirchman D, Graham S, Reish D, Mitchell R (1982) Bacteria induce settlement and metamorphosis of Janua (Dexiospira) brasiliansis Grube (Polychaeta: Spirorbidae). J Exp Mar Biol Ecol 56:153-163

Lambert WJ, Todd CD (1994) Evidence for a water-borne cue inducing metamorphosis in the dorid nudibranch mollusc Adalana proxıma (Gastropoda: Nudibranchia). Mar Biol $120: 265-271$ 
Lin J (1990) Mud crabs predation on ribbed mussels in salt marshes. Mar Biol 107:103-109

Maki JS, Rittschof D, Schmidt AR, Snyder AG, Mitchell R (1989) Factors controlling attachment of bryozoan larvae: a comparison of bacterial films and unfilmed surfaces. Biol Bull 177:295-302

McDermott JJ (1960) The predation of oysters and barnacles by crabs of the family Xanthidae. Proc P Acad Sci 34: 199-211

McDermott JJ, Flower FB (1952) Preliminary studies of the common mud crabs on oyster beds of Delaware Bay. Conv Adr Natn Shellfish Assoc 1952:47-50

McDonald J (1977) The comparative intertidal ecology and niche relations of the sympatric mud crabs, Panopeus herbstii (Milne-Edwards) and Eurypanopeus depressus (Smith), at North Inlet, South Carolina, USA (Decapoda: Brachyura: Xanthidae). PhD Dissertation, University of South Carolina, Columbia, SC

McDonald J (1982) Divergent life history patterns in the cooccurring intertidal crabs Panopeus herbstii and Eurypanopeus depressus (Crustacea: Brachyura: Xanthidae). Mar Ecol Prog Ser 8:173-180

Meadows PS, Campbell JI (1972) Habitat selection by aquatic invertebrates. Adv Mar Biol 120:271-382

Meyer DL (1994) Habitat partitioning between the Xanthid crabs Panopeus herbstii and Eurypanopeus depressus on intertidal oyster reefs (Crassostrea virginica) in southeastern North Carolina. Estuaries 17:674-679

Morse DE (1990) Recent progress in larval settlement, metamorphosis: closing the gaps between molecular biology and ecology. Bull Mar Sci 46:465-483

O'Connor NJ, Judge ML (1997) Flexibility in timing of molting of fiddler crab megalopae: evidence from in situ manipulation of cues. Mar Ecol Prog Ser 146:55-60

Pawlik JR (1992) Induction of marine invertebrate larval settlement: evidence for chemical cues. In: Paul VJ (ed) Ecological roles of marine natural products. Cornell University Press, Ithaca, p 189-236

Pearce CM, Scheibling RE (1990) Induction of settlement and

Editorial responsibility: Otto Kinne (Editor)

Oldendorf/Luhe, Germany metamorphosis in the sand dollar Echinoarachnius pama: evidence for an adult-associated factor. Mar Biol 107 : $363-369$

Pearce CM, Scheibling RE (1991) Effect of macroalgae, microbial films, and conspecifics on the induction of metamorphosis of the green sea urchin Strongylocentrotus droebachiensis (Müller). J Exp Mar Biol Ecol 54:167-179

Rodríguez SR, Ojeda FP, Inestrosa NC (1993) Settlement of benthic marine invertebrates. Mar Ecol Prog Ser 97: 193-207

Rowley RJ (1989) Settlement and recruitment of sea urchins (Strongylocentrotus spp.) In a sea-urchin barren ground and a kelp bed: are populations regulated by settlement or post-settlement processes? Mar Biol 100:485-494

Ryan EP (1956) Observations on the life histories and the distribution of the Xanthidae (mud crabs) of Chesapeake Bay, Am Midl Naturalist 56:138-162

Weber JC, Epifanio CE (1996) Response of mud crab megalopae to cues from adult habitat. Mar Biol 126:655-661

Welch JM, Epifanio CE (1995) Effect of variations in prey abundance on growth and development of crab larvae reared in the laboratory and in large field-deployed enclosures. Mar Ecol Prog Ser 116:55-64

Welch JM, Rittschof D, Bullock TM, Forward RB Jr (1997) Effects of chemical cues on settlement behavior of blue crab Callinectes sapidus postlarvae. Mar Ecol Prog Ser 154:143-153

Whetstone JM, Eversole AG (1981) Effects of size and temperature on mud crabs, Panopeus herbstii, predation on hard clams, Mercenaria mercenaria. Estuaries 4:153-156

Williams AB (1984) Shrimps, lobsters, and crabs of the Atlantic coast of the eastern United States, Maine to Florida. Smithsonian Institution Press, Washington, DC

Wolcott DL, DeVries MC (1994) Offshore megalopae of Callinectes sapidus: depth of collection, molt stage, and response to estuarine cues. Mar Ecol Prog Ser 109:157-163

Zimmer-Faust RK, Tamburri MN (1994) Chemical identity and ecological implications of a waterborne, larval settlement cue. Limnol Oceanogr 39:1075-1087

Submitted: February 22, 1999; Accepted: May 28, 1999

Proofs received from author(s): March 7, 2000 